\section{Prevalence of obesity in preschool children from five towns in São Paulo State, Brazil}

\author{
Prevalência de obesidade infantil em cinco \\ municípios do Estado de São Paulo, Brasil
}

\author{
1 Instituto de Saúde, \\ Secretaria do Estado \\ da Saúde de São Paulo, \\ São Paulo, Brasil. \\ 2 Faculdade de Saúde \\ Pública, Universidade de \\ São Paulo, São Paulo, Brasil. \\ Correspondence \\ S. R. D. M. Saldiva \\ Instituto de Saúde, \\ Secretaria do Estado \\ da Saúde de São Paulo. \\ Rua Santo Antônio 590, \\ São Paulo, SP \\ 01314-000, Brasil. \\ sm_saldiva@uol.com.br
}

\begin{abstract}
Health and nutritional characteristics of children under 5 years of age were investigated through a cross-sectional study in 5 small cities from different regions in the State of São Paulo, Brazil, which displayed different socioeconomic profiles: Bady Bassit, Bofete, Jaborandi, Morungaba, and Riversul. Data were obtained using a systematic sampling from the 1991 National Census. Anthropometric data were collected from all children under 5 years of age living in the selected households. Nutritional status was determined by height/age and weight/height according to the National Center for Health Statistics - NCHS standards. Stunting was defined as $H A Z$ below - $2 Z$ scores and obesity as $W H Z$ above $2 Z$ scores. The study sample consisted of 987 children (490 boys and 497 girls). Prevalence of obesity was 6.6\% (65) and stunting 5.0\% (51). Per capita income displayed a significant and positive association with obesity ( $p=0.018)$, in contrast to an inverse association with stunting $(p=0.038)$.
\end{abstract}

Obesity; School Health; Infant Nutrition; Anthropometry
Silvia Regina Dias Medici Saldiva 1 Maria Mercedes Loureiro Escuder 1 Sonia Isoyama Venâncio 1 Maria Helena D'Aquino Benicio 2

\section{Introduction}

The developing countries are undergoing a complex and explosive set of changes in their level of urbanization, access to schooling, and health care which modify the population's living conditions and habits. The phenomenon known as nutritional transition has been described within this scenario, where individuals in the same community can present either under- or overeating.

In Brazil, the nutritional transition has been discussed and evaluated in different studies 2 that have monitored the change in the prevalence of malnutrition and obesity over the course of relatively long windows of time (on the order of decades). Studies of two populationbased birth cohorts (1982 and 1993) of infants in Pelotas, Rio Grande do Sul State 3, showed a decline of $42.1 \%$ in the weight/age deficit, a slight increase in the height/age deficit (13.1\%), and an increase of $40.3 \%$ in the prevalence of obesity. In the city of São Paulo, Monteiro \& Conde 4 showed that in a 22 -year period the prevalence of malnutrition remained stable $(2.4 \%)$ and that obesity increased (to $3.8 \%$ ) but remained low and restricted to high-income children.

The above-mentioned studies, conducted in medium and large cities, indicate an increasing trend towards obesity in children, with a significant and positive association with family income. 
From the public-health point of view, childhood obesity is as worrisome as malnutrition. The latter has various adverse effects on children's health, including increased mortality, increased frequency, duration, and severity of infectious diseases, and cognitive deficits. Obesity is associated with an increased risk of hypercholesterolemia, arterial hypertension, ischemic myocardiopathy, diabetes, and bone and joint problems, among others 5 .

The current study aims to contribute to the assessment of the possible role of family income on the prevalence of height deficit and childhood obesity, through a cross-sectional study in 5 small cities in the State of São Paulo. These results are part of the survey entitled Childhood Health and Nutrition in Five Municipalities in the State of São Paulo, conducted by the Institute of Health under the Coordinating Board for Research Institutes, São Paulo State Health Secretariat (IS/CIP/SES-SP) and the Nucleus for Epidemiological Research in Nutrition and Health (NUPENS/USP). This survey is part of the project Use of Social and Economic Indicators in Nutrition and Health Diagnosis and Planning, coordinated by the Institute of Collective Health at the Federal University in Bahia.

\section{Methods}

A household survey was conducted in five municipalities (counties) in the State of São Paulo Bady Bassit, Bofete, Jaborandi, Morungaba, and Riversul - selected on the basis of the following criteria: population less than 10 thousand, participation in the Food and Nutritional Surveillance System (SISVAN-SP), and in the Project Breastfeeding and Municipalities, developed at the Institute of Health. The attempt was to select municipalities from different geographic areas in the State of São Paulo and with different social development indices. The tool used for this purpose was the São Paulo Social Responsibility Index (IPRS), prepared by the SEADE Foundation at the request of the São Paulo State Legislature (http://www.seade.gov. br/cgi-bin/lingcv98/spd_01.ksh, accessed on 15/Oct/2001).

The index was obtained from summary indicators of wealth, life expectancy, and schooling, calculated for two periods, 1992 and 1997. The municipalities were classified in 5 groups: (1) those that acted as regional hubs; (2) economically dynamic municipalities but with low social development; (3) healthy municipalities but with low economic development; (4) municipalities with low economic development and in a state of social transition; and (5) municipalities with both low economic and social development.

The target municipalities presented the following IPRS values: Morungaba 2; Bady Bassit 3; Jaborandi 3; Bofete 4; and Riversul 5.

The principal objective of the sample design was to estimate the prevalence of malnutrition in children from 0 to 4 years of age in each of the 5 selected municipalities. Using the EpiInfo EPITABLE program, was calculated the sample size, using as parameters the predicted values for prevalence of childhood malnutrition (height/age deficit < -2SD) in each municipality, as published by Benício \& Monteiro 6 , and with a precision of $5.0 \%$.

Given the lack of a registry of children, we opted for a systematic sampling of households, with interviews involving all children from 0 to 4 years of age residing in the selected household. In order to obtain the number of households to be selected, we used estimates of the mean number of children per household in each municipality and in each zone (rural vs. urban). These estimates were also obtained through data from the 1996 Population Count. With this information in hand, the intervals between households to be surveyed in a systematic drawing for each municipality was calculated. After verbal consent by parents or guardians, all children under five years of age and residing in the selected household were weighed and measured.

The survey was conducted from October to November 2001.

Anthropometric measures were taken by trained nutritionists using a digital scale (TANITA brand), accurate to $200 \mathrm{~g}$. Children over two years of age were measured with a SECA stadiometer, and those under two years of age were measured with a wooden infantometer especially built for this purpose.

Characterization of children's linear and weight growth in the children was performed by comparing the height/age and weight/height anthropometric indicators with the reference curve from the U.S. National Center for Health Statistics 7, as recommended by the World Health Organization 7. Analysis of nutritional status used the EpiInfo program, version 6.04.

Twenty-seven children were excluded from the sample based on at least one of the following conditions: weight less than or greater than 5 standard deviations from the expected median for age and sex, height less than 5 standard deviations or greater than 3 standard deviations from the expected median for age and sex, and weight less than 4 standard deviations or greater than 5 standard deviations from the expected median for height and sex. 
Obesity was defined using the indicator weight/height greater than 2 standard deviations from the population reference curve for sex and age. Height deficit was defined as the indicator height/age less than -2 standard deviations from the population reference for sex and age 8 .

For purposes of analysis, per capita family income was expressed as units of the prevailing Brazilian monthly minimum wage (R\$ 180.00 or approximately U\$80.00) $(<0.25,0.25$ to $0.5,0.5$ to 0.75 , and $>0.75$ times the minimum wage per capita). The lower category was based on the definition of the absolute poverty line $(<0.25$ minimum wage) used by Pastore et al., Jaguaribe, and Tolosa, as quoted by Iunes ${ }^{9}$. Class intervals of similar sizes were adopted for the other per capita income strata.

Data analysis used descriptive methods and contingency tables, applying the chi-squared test with the help of the SPSS program, version 7.0.

In relation to ethical aspects, this was a lowrisk study and was conducted in conformity with Ruling 196/96 of the Brazilian Ministry of Health.

\section{Results}

The sample consisted of 987 children under 5 years (490 boys and 497 girls), distributed among the 5 target municipalities as follows: 191 in Bady Bassit, 173 in Bofete, 196 in Jaborandi, 172 in Morungaba, and 255 in Riversul. In rela- tion to the location of households, $87 \%$ (858) of the children resided in the urban zone and $13 \%$ (129) in the rural zone.

Prevalence of obesity was $6.6 \%$ and height deficit $5.2 \%$.

Figure 1 shows the distribution of family income for children studied in the 4 per capita minimum wage categories in the five municipalities.

Prevalence rates for obesity and height deficit were not homogeneous in the five municipalities, and the latter was significant $(\mathrm{p}=$ 0.003) (Figure 2).

Analyzing the distribution of prevalence rates for height deficit and obesity by age bracket (Figure 3), no significant difference was observed.

In the analysis of prevalence of height deficit and obesity broken down according to four per capita income categories, significant differences were observed. As Figure 4 shows, the prevalence of obesity increases with increased per capita income $(p=0.018)$, while height deficient showed an inverse trend $(\mathrm{p}=0.038)$.

Indicators of nutritional status showed similar profiles for both sexes and for level of maternal schooling (data not shown).

\section{Discussion}

According to the results, family income is an important modulating factor for both height deficit and obesity. As shown in Figure 4, there

Figure 1

Distribution in 4 categories of per capita income (expressed as times the prevailing minimum wage)

in 5 municipalities in the State of São Paulo, Brazil, 2001.

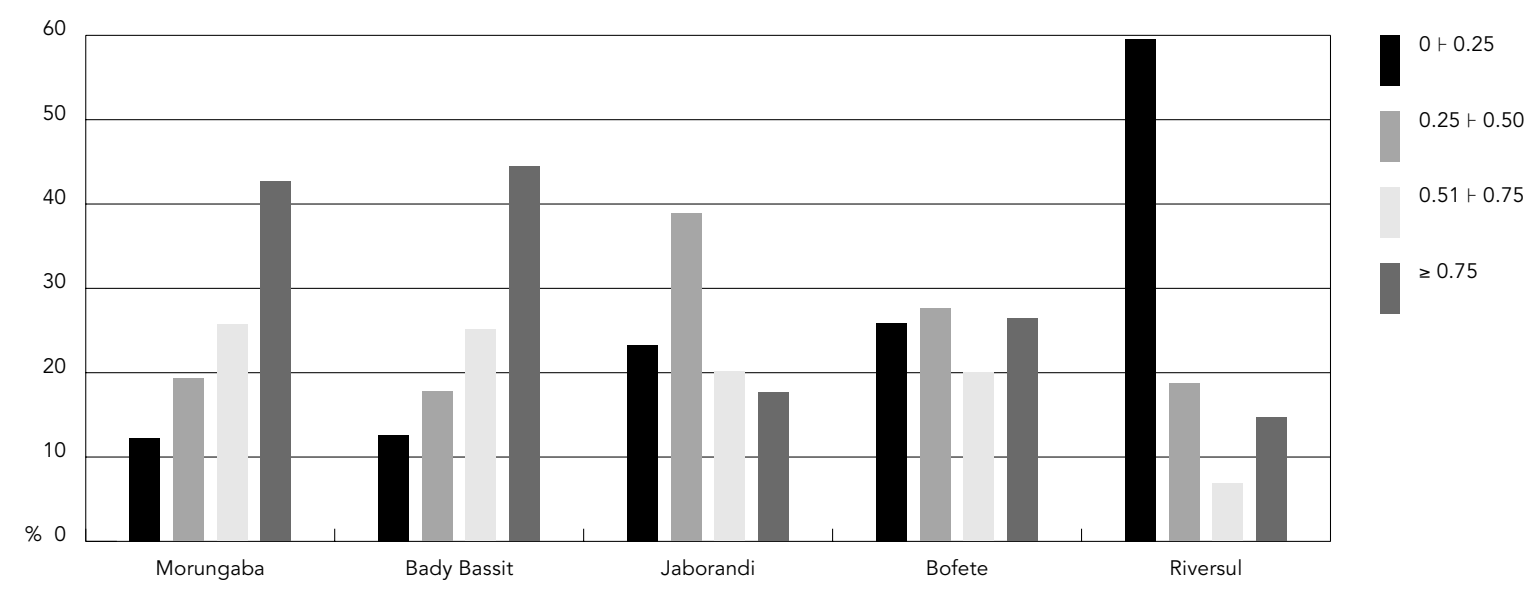


Figure 2

Prevalence of height deficit and obesity and children under 5 years of age residing in five municipalities in the State of São Paulo, Brazil, 2001.

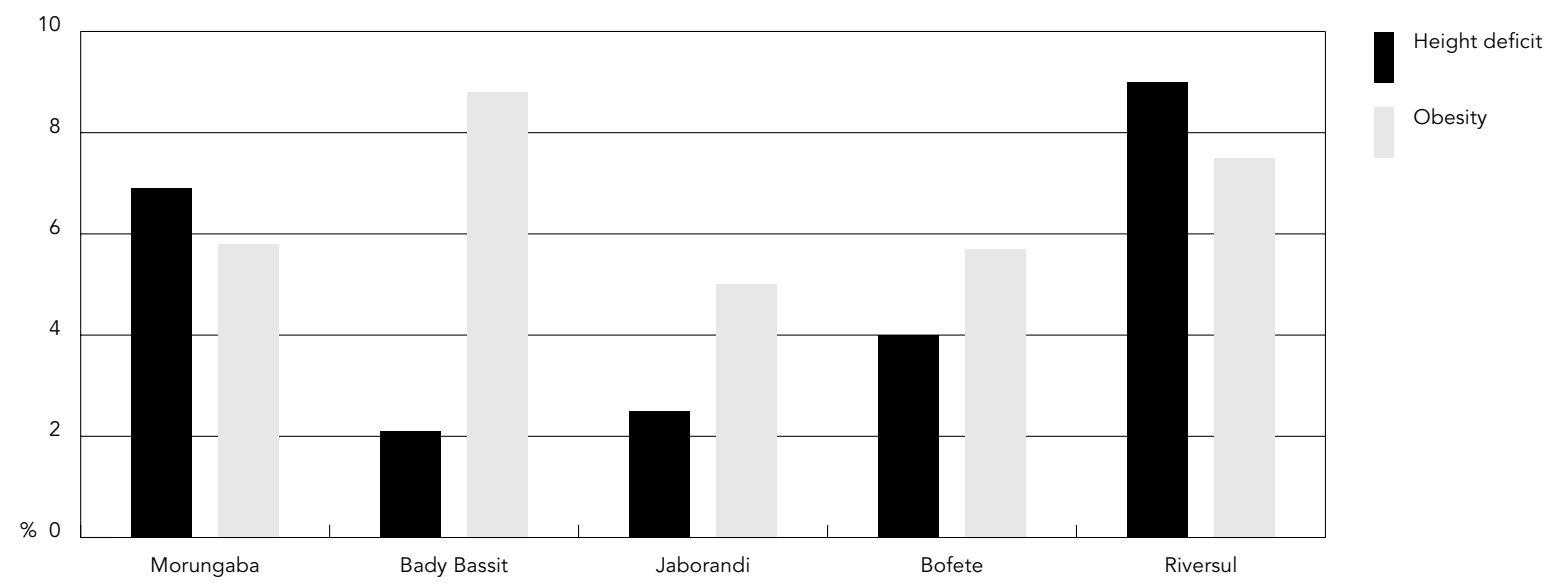

\section{Figure 3}

Prevalence of height deficit and obesity according to age bracket (in months) in children under 5 years of age residing in 5 municipalities in the State of São Paulo, Brazil, 2001.

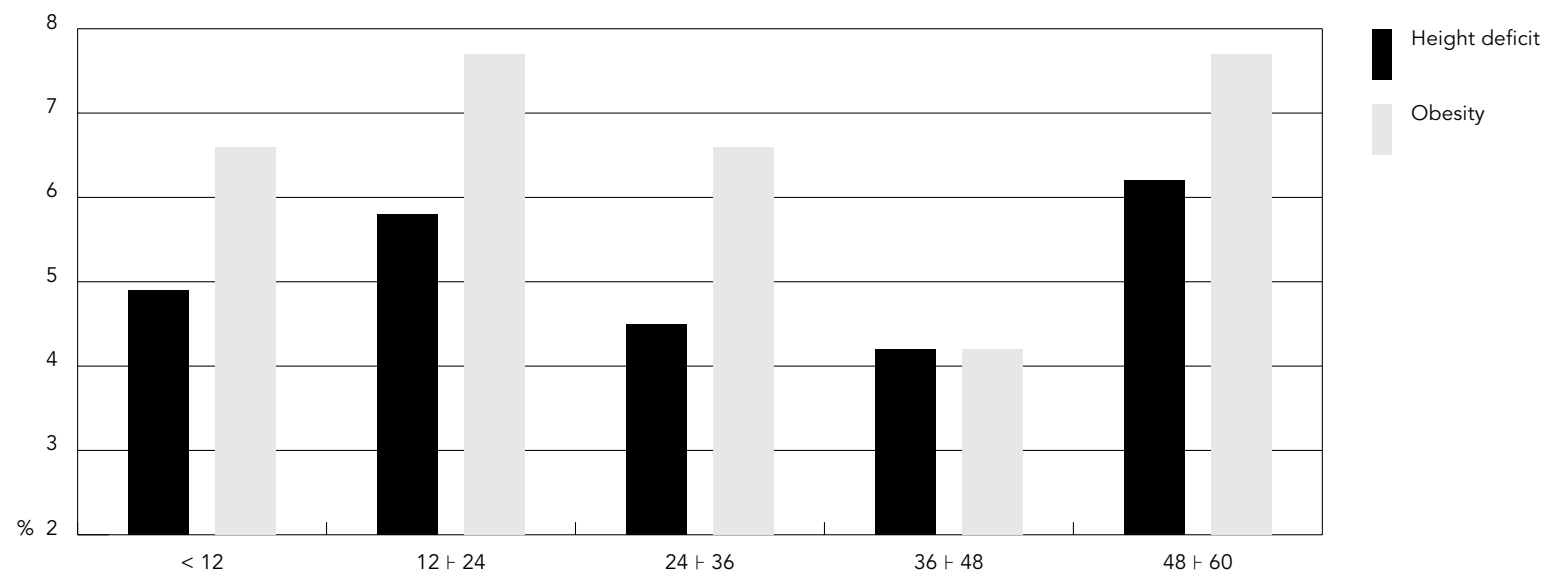

is a clear upward trend toward height deficit as per capita family income decreases. In the opposite direction, prevalence of obesity increases as income increases, from some $5.0 \%$ in children with per capita family incomes less than 0.25 times the minimum wage to $11.0 \%$ in children with income greater than 0.75 times the per capita minimum wage. This finding confirms the results obtained in a previous study in São Paulo 4. A similar trend was shown in the Pelotas cohorts (1982 and 1993), although in children under one year of age and with higher per capita income cutoff points 3 .

According to the Pelotas study (in the 1993 cohort), some $10.0 \%$ of the children monitored for 1 to 4 years became overweight 10 .

The five target municipalities showed higher prevalence rates for height deficit than the 
rates reported in the city of São Paulo in 1995/ 19964 , where the height deficit prevalence in the lowest income bracket was only $3.9 \%$, that is, half the rate identified in our study (Figure 4). This finding indicates that the problem of height deficit has not been properly controlled in the target municipalities, given that the expected height deficit rate based on the NCHS reference is $2.3 \%$.

The prevalence of height/age deficit at four years of age in children from the Pelotas cohort was very similar to that obtained in the current study, some $4.5 \% 10$.

In relation to obesity, the target municipalities showed approximately double the prevalence found in the city of São Paulo 4 , when evaluating the highest income bracket. For the sample of children as a whole, obesity prevalence was $6.6 \%$, approximately three times higher than expected according to the reference distribution (NCHS). In the Pelotas cohort 10 the prevalence of obesity $(9.3 \%)$ was higher than for the five municipalities as a whole, but very similar to that found in the municipality of Bady Bassit.

The high prevalence of malnutrition found in this study may be explained by the low social development indicators in some of the municipalities comprising the sample. Exemplifying, Morungaba belongs to IPRS group 2, that is, an economically dynamic municipality but with low social development. This profile was partially confirmed by our findings, showing a high prevalence of height deficit $(7.0 \%)$. According to the IPRS definition, this is a characteristic of municipalities that are located around a regional hub, in this case the larger city of Campinas, which displays relatively great wealth due to an increasing economic and demographic pace, yet with precarious social indicators, such as those related to life expectancy and schooling. However, Bady Bassit and Jaborandi, which belong to group 3, classified by the IRPS as "healthy, but with low economic development" show a contrast between their low level of local wealth and their significant positive schooling and life expectancy levels. The malnutrition rates in these municipalities were $2.1 \%$ and $2.6 \%$, respectively. Note that Riversul, characterized by low economic and social development, showed the highest prevalence of malnutrition (9.0\%) and the second highest obesity rate $(7.5 \%)$ among the five municipalities.

Previous studies have demonstrated a clear association between low family income, low maternal schooling, intestinal parasites, and malnutrition in small municipalities in the State of São Paulo 11,12.
Figure 4

Prevalence of height deficit and obesity according to per capita income categories (expressed as times the prevailing minimum wage) in children under 5 years of age residing in 5 municipalities in the State of São Paulo, Brazil, 2001.

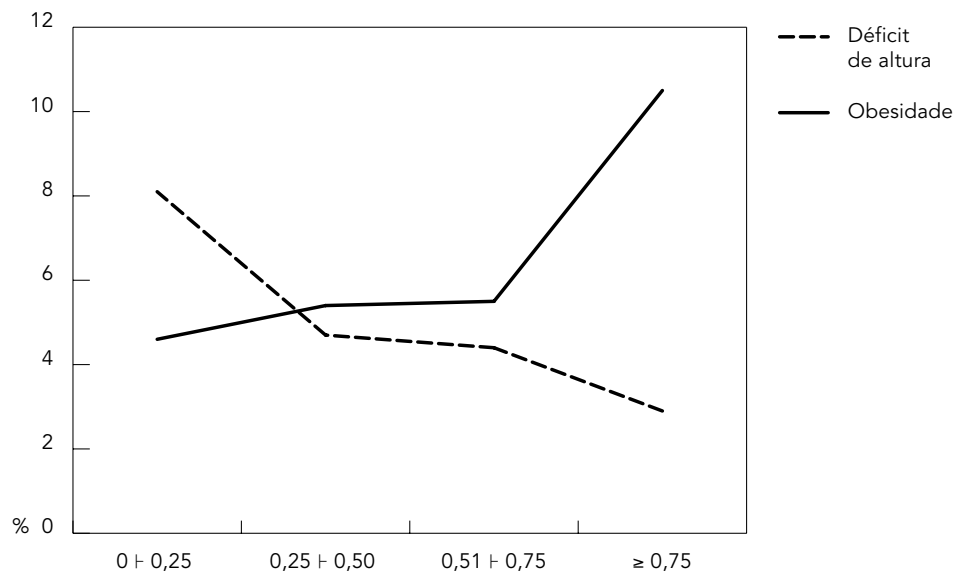

According to studies by Sawaya et al. 13,14,15, another aspect to be considered in relation to the prevalence of chronic childhood malnutrition is the potential for development of obesity in adulthood. It has been demonstrated that malnourished children have their ability to metabolize fat compromised, a factor that can predispose to obesity. This metabolic alteration, when associated with inadequate eating habits, has actually been implicated in the pathogenesis of obesity in developing countries. Thus, we should call the attention of our health systems managers to the quality of intervention measures to combat malnutrition, since these same children may develop obesity in the near future.

Various factors probably contribute significantly to the high prevalence of obesity found in our sample, such as reduced physical activity and increased consumption of fats and single-chain carbohydrates.

Obviously the current study was not designed in such a way as to evaluate all the possibilities governing the high rate of malnutrition and obesity in the target population (Figure 2). Nevertheless, the results are sufficiently important to call attention to the fact that nutritional interventions should deal with both problems, especially in municipalities with characteristics that are similar to those in our study. 


\section{Resumo}

Com o intuito de conhecer a saúde e nutrição de crianças menores de cinco anos que residiam em municípios de pequeno porte no Estado de São Paulo, Brasil, foi realizado um inquérito domiciliar em cinco municípios: Bady Bassit, Bofete, Jaborandi, Morungaba e Riversul, localizados em diferentes regiões geográficas e com perfis distintos de desenvolvimento. A coleta de dados foi realizada por meio de sorteio sistemático dos domicílios com base no Censo Demográfico de 1991. Foram consideradas com déficit de altura crianças com o índice alturalidade menor que -2 scores $Z$, $e$ para a obesidade aquelas com o índice de pesolaltura maior que 2 scores $Z$, segundo o National Center for Health Statistics, Estados Unidos. A amostra foi composta por 987 crianças (490 meninos e 497 meninas). A prevalência de obesidade foi de 6,6\% e o déficit de altura de 5,2\%. Na análise das prevalências de déficit de altura e de obesidade desagregadas por categorias de renda per capita em salários mínimos, são encontradas diferenças significativas, onde a prevalência de obesidade aumenta com o aumento da renda per capita ( $p=0,018$ ), enquanto que o déficit de altura apresentou comportamento inverso ( $p=0,038$ ).

Obesidade; Saúde Escolar; Nutrição Infantil; Antropometria

\section{References}

1. Monteiro CA, Mondini L, Souza ALM, Popkin BM. The nutrition transition in Brazil. Eur J Clin Nutr 1995; 49:105-13.

2. Post CL, Victora CG, Barros FC, Horta BL, Guimarães PRV. Desnutrição e obesidade infantis em duas coortes de base populacional no Sul do Brasil: tendências e diferenciais. Cad Saúde Pública 1996; 12 Suppl 1:49-57.

3. Monteiro CA, Conde WL. Tendência secular da desnutrição e da obesidade na infância na cidade de São Paulo (1974-1996). Rev Saúde Pública 2000; 34 Suppl 6:52-61.

4. Eckersley RM. Losing the battle of the bulge: causes and consequences of increasing obesity. Med J Aust 2001; 174:590-2.

5. Benício, Monteiro. Desnutrição infantil nos municípios brasileiros - risco de ocorrência. São Paulo: Núcleo de Pesquisas Epidemiológicas em Nutrição e Saúde, Universidade de São Paulo/ Brasília: Fundo das Nações Unidas para a Infância; 1997.

6. Hamil PVV, Drizd TA, Johnson CL, Reed RB, Roche AF, Moore WM. Physical growth: NCHS percentiles. Am J Clin Nutr 1979; 32:607-29.

7. World Health Organization. Physical status: the use and interpretation of anthropometry. Geneva: World Health Organization; 1995. (Technical Report Series 854).

8. World Health Organization. Global database on child growth and malnutrition. Geneva: World Health Organization; 1997.

9. Iunes RF. Mudanças no cenário econômico. In: Monteiro CA, organizador. Velhos e novos males

\section{Contributors}

S. Saldiva contributed to the adaptation of the questionnaire for the municipalities in the State of São Paulo, data analysis, and the article's main draft. M. M. Escuder contributed to the sample design and drafting of the article. S. I. Venancio collaborated in the adaptation of the questionnaire for the municipalities in the State of São Paulo and drafted the article. M. H. D'A. Benício contributed to the adaptation of the questionnaire for the municipalities in the State of São Paulo and did the final revision of the article.

\section{Acknowledgments}

The authors wish to thank the Funding Agencies for Studies and Projects (FINEP) for its financial support, Prof. Mauricio Lima Barreto from the Institute of Collective Health at the Federal University in Bahia, and the Mayors and Secretaries of Health from the five municipalities for their logistic support in conducting this study. da saúde no Brasil. São Paulo: Editora Hucitec; 1995. p. 93-114.

10. Gigante DP, VictoraCG, Araújo CLP, Barros FC. Tendências no perfil nutricional das crianças nascidas em 1993 em Pelotas, Rio Grande do Sul, Brasil: análises longitudinais. Cad Saúde Pública 2003; 19 Suppl 1:141-7.

11. Saldiva SRDM, Silveira AS, Philippi ST, Torres DM, Mangini AC, Dias RMD, et al. Ascaris-Trichuris association and malnutrition in Brazilian Children. Paediatr Perinat Epidemiol 1999; 13:89-98.

12. Saldiva SRDM, Carvalho HB, Castilho VP, Struchiner CJ, Massad E. Malnutrition and susceptibility to enteroparasites: reinfection rates after mass chemotherapy. Paediatr Perinat Epidemiol 2002; 16:166-71.

13. Sawaya AL, Dallal G, Solymos G, Souza MH, Ventura ML, Roberts SB, et al. Obesity and malnutrition in a shantytown population in the city of São Paulo, Brazil. Obes Res 1995; 3 Suppl 2:107S-15S.

14. Sawaya AL, Grillo LP, Verreschi I, Silva CA, Roberts SB. Mild stunting is associated with higher susceptibility to the effects of high-fat diets: studies in a shantytown population in São Paulo, Brazil. J Nutr 1997; 128:415-20.

15. Sawaya AL, Roberts S. Stunting and future risk of obesity: principal physiological mechanisms. Cad Saúde Pública 2003; 19 Suppl 1:21-8.

Submitted on $23 / \mathrm{Jan} / 2003$

Final version resubmitted on 25/Nov/03

Approved on 10/Dec/2003 